\title{
Marketing Strategy for Welding Workshops in the New Normal Era after the Covid-19 Pandemic
}

\author{
Andika Isma $^{1 *}$, Andi Hidayatullah ${ }^{2}$, Agung Winarno ${ }^{3}$, Agus Hermawan ${ }^{4}$ \\ 1,2,3,4 Magister Manajemen, Fakultas Ekonomi, Universitas Negeri Malang \\ Email: andikaisma.1904137@ students.um.ac.id
}

(Received: 28 July 2020; revised: 14 August 2020; published: 23 September 2020)

\begin{abstract}
The Covid-19 pandemic has a major impact on all aspects and sectors of public life, especially business actors. The impact of the Covid-19 Pandemic was also experienced by welding workshops, one of which was the Barakka Las workshop. This study aims to determine the implementation of marketing strategies in the welding workshop business "Barakka Las" in the New Normal Era after the Covid-19 Pandemic through the creation and design of social media and websites. This research uses a qualitative approach with a case study research method. The data were obtained through collecting supporting theories and conducting in-depth interviews with the owner of the "Barakka Las" welding workshop. From the results obtained, in increasing brand loyalty and reaching wider consumers, Barakka Las implemented a digital marketing strategy through social media such as Instagram, Facebook, Twitter and Youtube and through websites with various interesting promotional content and additional information about the Covid-19 prevention protocol.
\end{abstract}

Keywords: marketing strategy, social media, website, covid-19 pandemic.

Copyright $\odot 2020$ Universitas Negeri Makassar. This is an open access article under the CC BY license (http://creativecommons.org/licenses/by/4.0/)

\section{INTRODUCTION}

New era normal or a new life order with new habits is the government's design in overcoming the problems resulting from the outbreak of the Covid-19 Pandemic (Artajaya, 2020; Aryawati, 2020; Bahri \& Arafah, 2020; Irawan, 2020; Putra, 2020). The Covid-19 pandemic has a major impact on all aspects and sectors in people's lives, especially in the economic sector (Hanoatubun, 2020; Kurniawansyah et al., 2020; Laura Hardilawati, 2020; Nasution et al., 2020; Nicola et al., 2020; Soetjipto, 2020). This occurs because of the decline in community activities outside the home due to the implementation of Large-Scale Social Restrictions (PSBB), which automatically causes a decrease in the amount of income or income in a business or business activity. This impact is not only felt by large industries.

The impact of the Covid-19 Pandemic on business actors was also experienced by the Welding Workshop business. The Welding Workshop business or business during the Covid-19 Pandemic experienced various problems that must be faced. The Large-Scale Social Restriction Regulation (PSBB) is one of the problems faced because it has an impact on reducing 
community or business activities outside the home and giving or reducing operational hours for various business activities (Damuri et al., 2020; Mungkasa, 2020; Silalahi \& Ginting , 2020). Apart from PSBB, competition for consumers during the Covid-19 Pandemic is also a problem that must be faced by Welding Workshop players because of the reduced demand for products or services from Welding Workshops. Such archives and documentation are stored as physical evidence of activity, both stored physically and digitally on the computer (Henni Zainal, Andi Idham Ashar, Darmawati Manda, Andi Tenry Sose, 2020).

In this New normal era, welding workshop actors slowly tried to get up and began to aggressively look for new strategies in an effort to survive and rise from adversity. One of the strategies considered to be able to overcome this problem is by implementing a marketing strategy. The right marketing strategy is needed by business actors, especially the Welding Workshop business to communicate their products or services to attract potential customers so that consumers have the confidence to use the services of the Welding Workshop in this New Nomral period.

Marketing strategy is a series of goals and objectives (Untari \& Fajariana, 2018), policies and rules that give direction to the company's marketing efforts from time to time (Nas, 2019; Wulandari \& Setyawati, 2018), at each level and reference and its applications, particularly as a company's response to the ever-changing competitive environment and conditions. Marketing strategy is an important thing in running a business because it is used in promotional activities to market products or services (Setiawati \& Widyartati, 2017). Meanwhile, promotion is also very important in running a business because promotion can increase consumer loyalty or to maintain trends in the existence of products or services in the market (Novianti et al., 2018; Sulistiani, 2017; Tjahjaningsih,

In line with the development of technology and information today, strategies in marketing have also begun to change to a more modern direction (Pranoto et al., 2019). In the past, only using promotional media such as newspapers, magazines, radio, or television, now marketing has been done with technology, via the internet, or what has become known as Digital Marketing (Pradiani, 2017). There are at least four benefits of digital marketing in maximizing a business, including saving promotional costs, reaching a wider market, as a means of increasing sales, and being a good means of connecting with consumers (Tresnawati \& Prasetyo, 2018).

Digital marketing is a marketing activity or promotion of a product or service using digital media or the internet (Atshaya \& Rungta, 2016; Bala \& Verma, 2018; Tresnawati \& Prasetyo, 2018). The purpose of digital marketing is to attract consumers and potential consumers quickly (Febriyantoro \& Arisandi, 2018; Purwana et al., 2017). As we know, the acceptance of technology and the internet in society is very broad, so it's no wonder digital marketing activities are the main choice by various business people or businesses.

One form of digital marketing is using social media (Febriyantoro \& Arisandi, 2018; Tresnawati \& Prasetyo, 2018). Social media is one of the media that can be used to carry out marketing activities to consumers because it is the form of interaction media most commonly used by people around the world today. In order to attract consumers, various ways can be done, one of which is through interesting content that can be conveyed through various types of social media such as instagam, facebook, twitter and Whatsapp (Tresnawati \& Prasetyo, 2018).

Conducting marketing activities through social media is the main choice for business actors today, especially at Welding Workshops, because the use of social media has become the 
Andika Isma; Marketing Strategy for Welding... |125

main pillar in delivering information (Suharyanto, 2016; Suryani, 2014). Social media can be used to communicate in business, help with marketing of products and services offered, communicate with customers and suppliers, complement brands, reduce costs and for online sales (Priambada, 2015).

In addition to social media, the use of websites is also a form of digital marketing that is suitable for use in welding workshops. The website is a method for displaying information on the internet, in the form of interactive text, images, sound and video and has the advantage of linking one document to another (hypertext) which can be accessed via a browser (Fatmawati et al., 2016 ). With a website, business actors can provide various information needed by customers or consumers related to products or services owned by a business because the website is very easy to access anywhere and anytime so that it provides many benefits for business people. Management of the strategic assets of the famly business is oriented towards increasing competitiveness and business performance (Henni Zainal, Muhammad Rakib, Andi Idham Ashar, Darmawati Manda, Andi Tenry Sose, Ignasius Setitit, 2020; Henni Zainal, Parinsi, Indonesia, Hasan, \& Makassar, 2018).

Most of the business people have started to switch to using digital systems. Actually, this digital system has long been known and entered Indonesia. However, after the arrival of the Covid-19 Pandemic, only business people started to become aware. In fact, they seemed to have snapped up from their long sleep so far. They just realized that the use of digital systems is a necessity that must be owned.

The use of social media and websites can indeed provide convenience in the process of promotion and buying and selling carried out by business people or at welding shops to market products and can minimize costs. However, there are still many business actors who do not understand the use of social media to market their business, they are still doing traditional marketing, namely by marketing products directly to consumers who only have a small area coverage. Usually, business actors, including the Welding Workshop, do not know about marketing using social media and websites.

The purpose of this study was to determine the implementation of marketing strategies in the welding workshop business in the New Normal Era after the Covid-19 Pandemic at Barakka Las . While the benefits of the results of this study are being able to design or own social media and websites that can be used to develop a business, can provide advantages in marketing products, become a means of promotion and efficient delivery of information to the wider community and increase knowledge about manufacture, design, use and learning related to social media and websites.

\section{METHOD}

This study uses a qualitative research approach. This research was conducted to determine the implications of the marketing strategies used by the welding shop business to increase consumer loyalty to the product or service brands provided. The research method used by researchers is to use the case study method. Researchers use case studies as a research method because researchers want to find and know and get accurate information about the themes that researchers take in this study. 
This study uses several data collection techniques such as interviews, observation, documentation, literature study and online data search. This data collection technique is intended to obtain the information and data needed in this study.

The subject of this research is Barakka Las, which is one of the welding shops in South Sulawesi which operates and serves various metal-based construction products, such as sliding doors, iron fences, canopies, window trellises, stair railings, water towers, steel construction. and so forth. Barakka Las is one of the Welding Workshop businesses that was affected by Covid-19. Direct interviews were conducted with company owners as key informants.

The object of this research is the marketing strategy. From the subject and object of the study, this study aims to determine the implications of the applied marketing strategy in increasing brand loyalty in the Welding Workshop business.

\section{RESULTS AND DISCUSSION}

Barakka Las was established on August 20, 2019, is one of the Welding Workshop businesses which is located at Jalan Dr. Samratulangi No.70 Pinrang RT.001 RW.001 Pinrang Village, Watang Sawitto District, Pinrang Regency, South Sulawesi. At first, Barakka Las was only an assignment or requirement of the owner's entrepreneurship course. However, after the owner completed his studies at a state university in Makassar City, the Welding Workshop business was finally continued to this day.

Currently, Barakka Las operates and serves various metal-based construction products, such as sliding doors, iron fences, canopies, window trellises, stair railings, water towers, steel construction and so on. Barakka Las has a fairly wide target market, ranging from housing areas that are still new to old housing that requires construction services.

The Covid-19 pandemic which has a wide impact on the world, especially the Welding Workshop business, has made business people pay more attention to their marketing strategies so that or can continue to operate and get customers. The marketing strategy implemented by Barakka Las is to use digital marketing. Digital marketing is considered to be more effective and efficient in communicating or marketing Welding Workshop services, especially in the New Normal era after the Covid-19 Pandemic. The application of digital marketing in the Las Barakka Las workshop business is carried out by utilizing social media and websites.

\section{Utilization of Social Media as Media Marketing of Barakka Las Products and Services in the Post-Covid-19 New Normal Era}

The internet has a role as a means or media to communicate the products that will be offered by business actors. Communication via the Internet is different from traditional media marketing communication, where there is a two way interaction between the seller and the buyer, the time for sending and receiving information by both of them can be measured in seconds so that there is communication harmony. This means that this digital marketing strategy through the internet can further speed up getting feedback or results from this marketing. One of 
the media on the internet that is used for marketing activities is social media. Some of the social media commonly used by many people today include Instagram, Facebook, Twitter, Whatsapp and Youtube (Tutiasri et al., 2020). In developing a marketing strategy using social media,

The first step taken by Barakka Las is to analyze the market and consumer behavior, in this pandemic era where people limit their activities outside the home and prefer to search for information on the internet or social media and the current tendency of people to prefer something instant and practical. The fact is that only with smartphones or cellphones and the internet, people can access and get all the information they want without the hassle.

The second step is to formulate goals. The purpose of creating social media is to increase sales, in this case, to increase the number of customers and get loyalty from customers to continue using the services of Barakka Las.

The third step is choosing the right social media. There are many types of social media that can be used to carry out marketing activities, but they need to be adjusted to the target market first, which media is most appropriate to be able to better reach potential consumers. The social media chosen by Barakka Las are Instagram, Facebook, Twitter, Whatsapp and Youtube.

Instagram, Facebook, Twitter, Whatsapp and Youtube are social media networks that are widely used by businesses and companies to help promote their products and services. On Instagram, Facebook, Twitter, Whatsapp and Youtube can post information to be shared. In the social media creation stage, researchers take advantage of the features available on social media to assist in marketing. Barakka Las uses a digital poster which is then given a caption or detailed information about the products or services offered on the poster. Unlike Youtube, marketing communication is not only in the form of digital posters but can also be in the form of videos. Following are the results of making social media for Barakka Las:
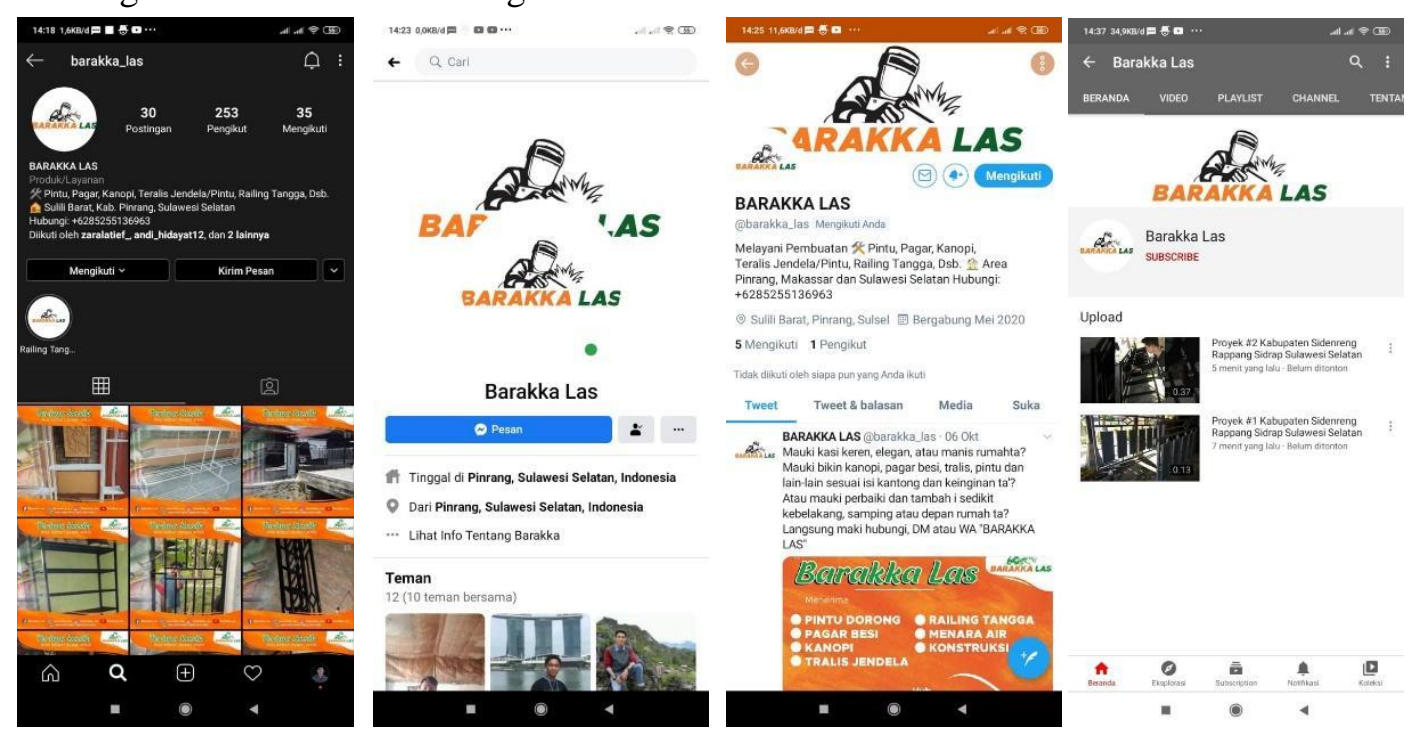


\section{Figure 1. Barakka Las's Social Media}

The fourth step is that social media has a feature that can create two-way communication quickly, directly reply to or comment on digital posters / videos that have been uploaded or posted. The content / message content of digital posters uploaded on every social media used includes facilities, photos or images of the products offered, contact persons, and in the caption of each post it is written that each product or service has been completed.

Social media as a digital marketing media carried out by Barakka Las before being applied, first carried out a problem analysis, by finding the problems being faced and also analyzing the audience in order to get the right target, then formulating or determining goals, namely in the form of increasing audience loyalty to the travel service, and then the selection of the use of digital posters and videos as the right media and communication channels to assist in the marketing communication process and additional information on the appeal to follow health protocols to prevent Covid-19 transmission.

\section{Utilization of the Website as a Marketing Media for Barakka Las Products and Services in the Post-Covid-19 New Normal Era}

In the current digital era, the role of information technology is important and is one of the supports for human needs and life. Information technology has now spread to become a medium used by people to carry out activities such as communication, discussion, transactions, information providers and their use in the business or business world. With the help of Information Technology, information delivery and marketing activities are easier to do, without being limited by time or place. Information technology delivery and marketing activities with the help of information technology can save costs and time in implementation.

Information technology is a supporting factor that is very effective today, especially after the Covid-19 Pandemic and allows the public to enjoy the various conveniences produced by technology. Technology is widely used as a means of promotion and information, one of which is the use of the website which currently plays a very important role in delivering information. The website is able to provide information to be more efficient and up to date. Websites are more easily accessible to people in various places using only the internet. Website is also a medium that is very suitable to introduce to the wider community the various potentials and advantages of a product or service that you want to market. Barakka Las is a Welding Workshop located in South Sulawesi.

In promoting its products, Barakka Las still uses less efficient methods. With the existence of a website as a promotional and information media, it can assist in the marketing of products and services at Barakka Las which is more efficient in terms of cost, energy and time, so that it is effective in achieving the goal of developing the Barakka Las business.

The creation of the Barakka Las Website began around October 2020 with the process starting with collecting data first and information about what needs Barakka Las requires in 
Andika Isma; Marketing Strategy for Welding... | 129

developing its business. After the information is collected, then the next process is to create a prototype of the website that will be made. Furthermore, from the prototype that has been produced, a High Fidelity concept is created which is applied to the creation of a website for Barakka Las. The website created is built using the PHP programming language with the framework used is Codeigniter. The database used in making this website is MySQL. The website creation took about 3 weeks beyond testing and implementation. The website can be accessed via a linkwww.barakkalas.com with a display as shown below.

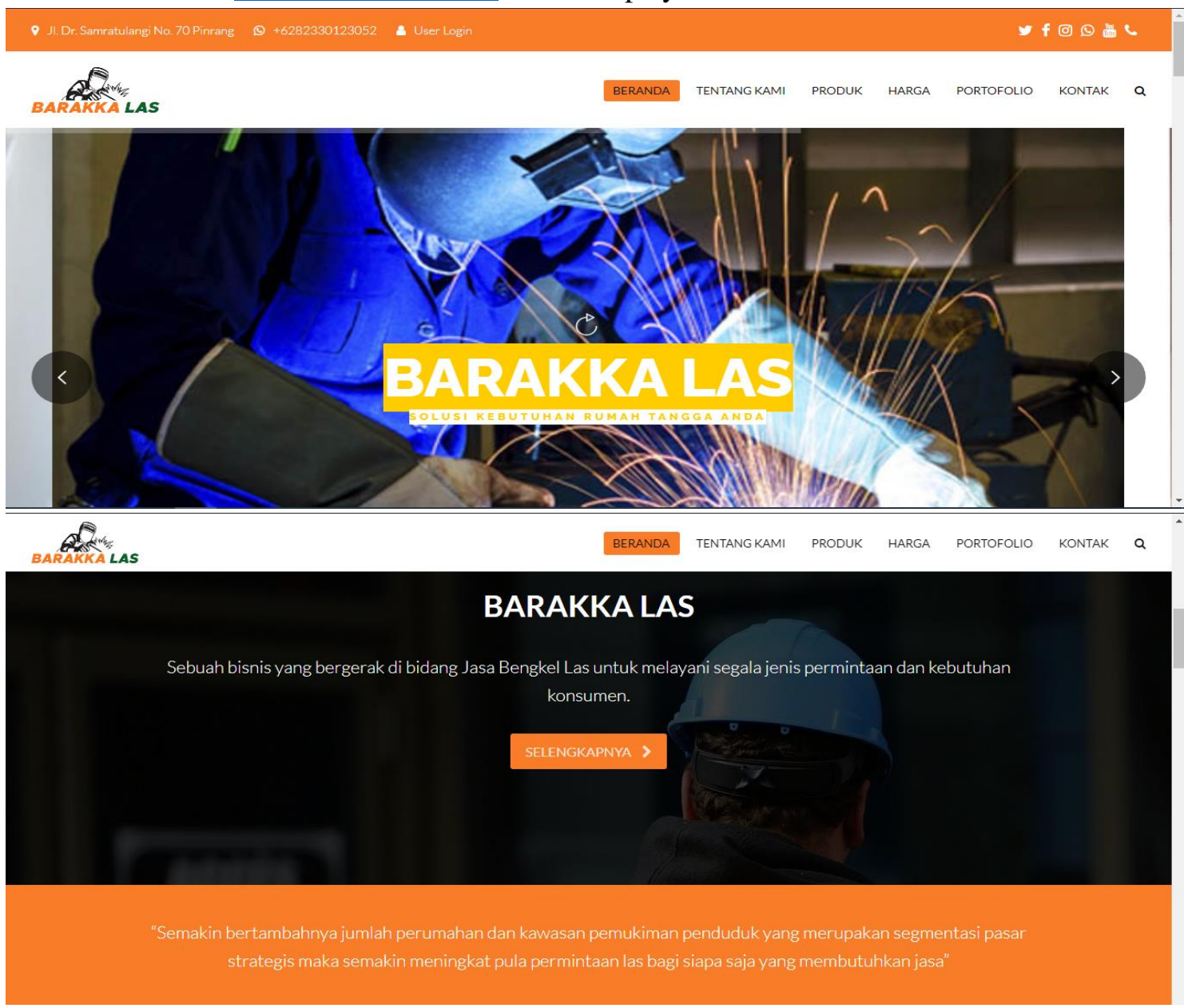

Figure 2. Barakka Las Website Homepage

Figure 2 above is general information of all information that can be accessed by visitors such as brief information about Berakka Las, Vision and Mission, advantages, aims and objectives of business establishment, target and market segmentation, and various other information related to Barakka Las. 


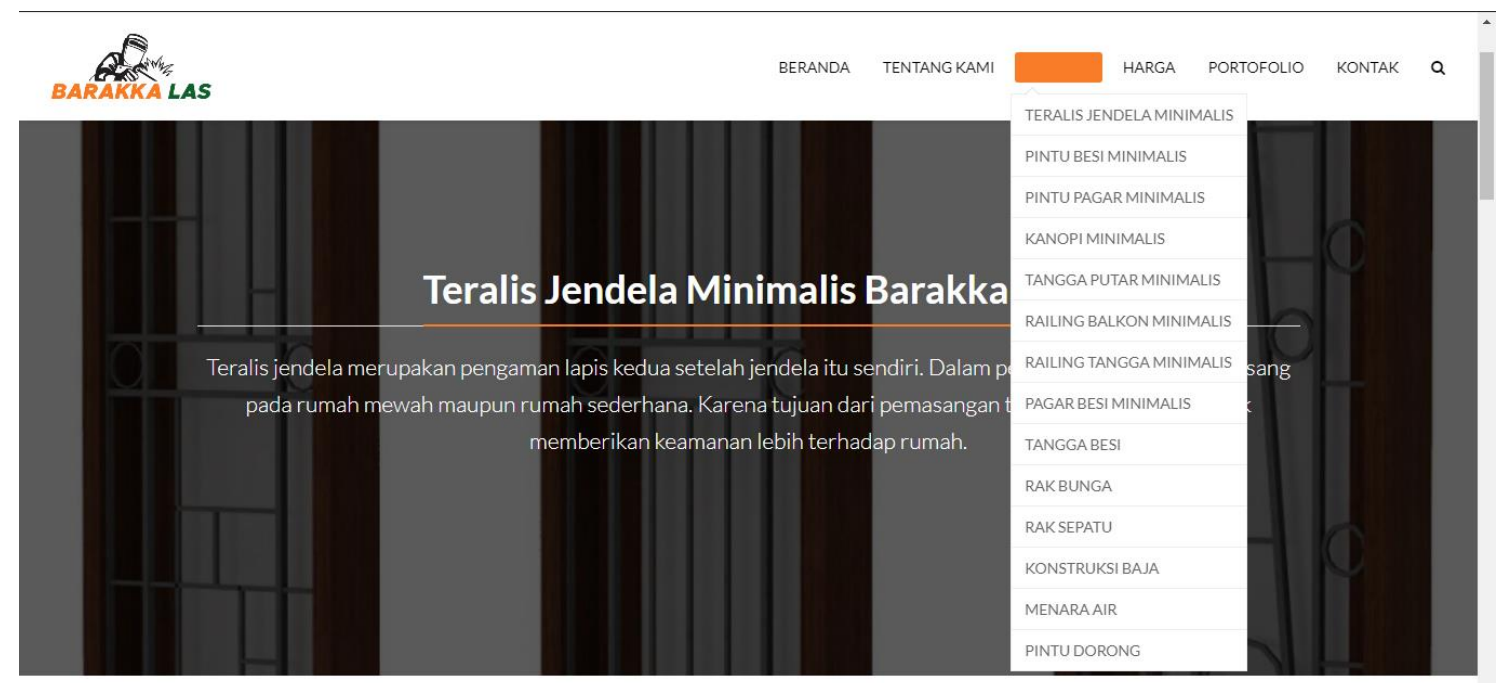

Figure 3. Barakka Las Products and Services List page

Figure 3 above is information regarding various products and services offered by Barakka Las. Some of Barakka's products and services include minimalist window trellis, minimalist iron doors, minimalist gate, minimalist canopy, minimalist rotary staircase, minimalist balcony railing, minimalist stair railing, minimalist iron fence, iron staircase, and various other products. On this product page, there is general information regarding the products offered such as an overview of the product, model, type of raw material, paint selection and various other information.

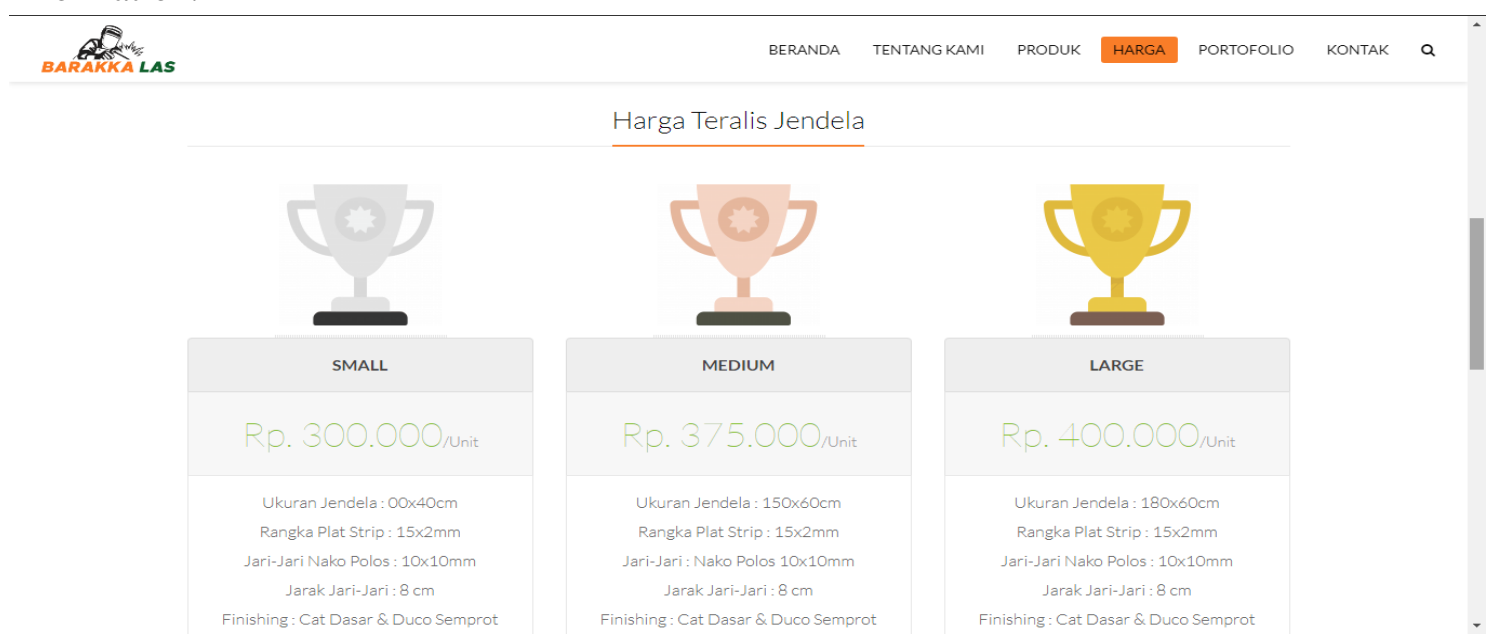

Figure 4. Barakka Las Product Price List page

Figure 4 above is information regarding the prices of various products and services offered by Barakka Las. On this product page, contains information such as things that you will 
Andika Isma; Marketing Strategy for Welding... |131

not get in most other welding workshops, size, raw material, anti-rust coating, paint used, choice of service types from small, medium to large sizes and various other information. including the ordering process.

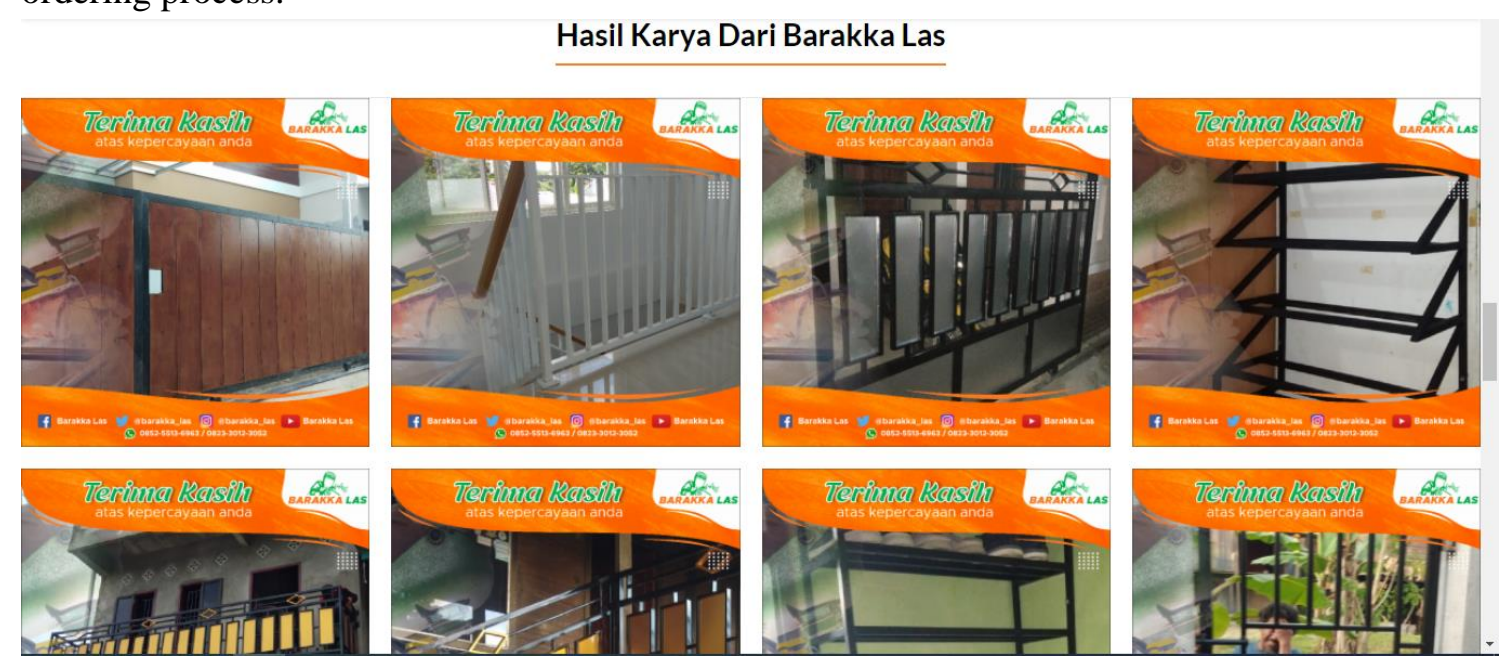

Figure 5. Barakk Las Portfolio Page

Figure 5 above is information related to the work or products and services that have been completed by Barakka Las.

\section{CONCLUSION}

Understanding the needs, wants and expectations of customers is very important and guides in making marketing strategies and policies. Creating value through the right marketing strategies and policies will cause consumers to become highly loyal customers.

The marketing strategy of the "Barakka Las" welding workshop business has been very appropriate to be applied given the changing patterns and life cycle of the people in the New Normal Era after the Covid-19 Pandemic which limited seeking information directly outside but preferring to use smartphones.

The use of social media such as Instagram, Facebook, Twitter and Youtube and through websites with messages and information that are disseminated using digital posters which are the main attraction for potential customers or consumers to get information and services easily through the internet and make customers continue to believe in using products and services offered.

\section{REFERENCES}

Amri, A. (2020). Dampak Covid-19 Terhadap UMKM di Indonesia. BRAND Jurnal Ilmiah Manajemen Pemasaran, 2(1), 123-131.

Artajaya, G. S. (2020). The Covid-19 Pandemic Perspective of Relegious Literature Studies in 
Bali. Widyadari: Jurnal Pendidikan, 21(2), 652-664.

Aryawati, N. P. A. (2020). Resiliensi Bisnis Pada UMKM Di Era Normal Baru Sebagai Upaya Kemandirian Ekonomi. Menyemai Benih Dharma Perspektif Multidisiplin, 47.

Atshaya, S., \& Rungta, S. (2016). Digital Marketing vs. Internet Marketing: A Detailed Study. International Journal of Novel Research in Marketing Management and Economics, 3(1), 29-33.

Bahri, S., \& Arafah, N. (2020). Analisis Manajemen Sdm Dalam Mengembangkan Strategi Pembelajaran Di Era New Normal. Tafkir: Interdisciplinary Journal of Islamic Education, 1(1), 20-40.

Bala, M., \& Verma, D. (2018). A critical review of digital marketing. M. Bala, D. Verma (2018). A Critical Review of Digital Marketing. International Journal of Management, IT \& Engineering, 8(10), 321-339.

Damuri, Y. R., Aswicahyono, H., Hirawan, F., Setiati, I., \& Simanjuntak, I. (2020). Langkah Pemberdayaan UMKM Dalam Menghadapi Covid-19.

Fatmawati, Irviani, R., Rachman, E. S., Putu, I., Anggie, A., \& Kristina, M. (2016). Tata Kelola Teknologi Informasi Sebagai Implementasi E-Government Pada Kabupaten Pemekaran Untuk Meningkatkan Potensi Daerah. Jurnal Teknologi Informasi, Proseding Senapati, 2015(Senapati), 249-257.

Febriyantoro, M. T., \& Arisandi, D. (2018). Pemanfaatan digital marketing bagi usaha mikro, kecil dan menengah pada era masyarakat ekonomi ASEAN. Jurnal Riset Manajemen Dan Bisnis Dewantara (JMD), 1(2), 61-76.

Hanoatubun, S. (2020). Dampak Covid-19 terhadap Prekonomian Indonesia. EduPsyCouns: Journal of Education, Psychology and Counseling, 2(1), 146-153.

Henni Zainal, Andi Idham Ashar, Darmawati Manda, Andi Tenry Sose, I. S. (2020). Effectveness of Archives Management Reviewed from Management Factors in Pattallassang Sub-District Office in Gowa Regency. Pinisi Business Administration Review, 2(1), 83-87.

Henni Zainal, Muhammad Rakib, Andi Idham Ashar, Darmawati Manda, Andi Tenry Sose, Ignasius Setitit. (2020). Strategy of human resources development in improving performance Apparatus in the Bone Regency Regional Inspectorate. Pinisi Business Administration Review, 2(1).

Henni Zainal, U. I. T., Parinsi, W. K., Indonesia, S. P., Hasan, M., \& Makassar, U. N. (2018). The Influence Of Strategic Assets And Market Orientation To The Performance Of Family Business In Makassar City , Indonesia, 17(6), 1-9.

Irawan, A. (2020). Challenges and Opportunities for Small and Medium Enterprises in Eastern Indonesia in Facing the COVID-19 Pandemic and the New Normal Era. TIJAB (The International Journal of Applied Business), 4(2), 79-89.

Kurniawansyah, H., Amrullah, A., Salahuddin, M., Muslim, M., \& Nurhidayati, S. (2020). Konsep Kebijakan Strategis Dalam Menangani Eksternalitas Ekonomi dari Covid-19 Pada Masyarakat Rentan di Indonesia. Indonesian Journal of Social Sciences and Humanities, 1(2), 130-139.

laura Hardilawati, W. (2020). Strategi Bertahan UMKM di Tengah Pandemi Covid-19. Jurnal Akuntansi Dan Ekonomika, 10(1), 89-98.

Mungkasa, O. (2020). Bekerja dari Rumah (Working From Home/WFH): Menuju Tatanan Baru 
Andika Isma; Marketing Strategy for Welding... |133

Era Pandemi Covid 19. The Indonesian Journal of Development Planning, 4(2), 126-150.

Nas, I. K. (2019). Peranan Strategi Pemasaran Dalam Upaya Meningkatkan Penjualan Garam pada UD Sumber Makmur di Desa Pinggir Papas Kecamatan Kalianget. Universitas Wiraraja.

Nasution, D. A. D., Erlina, E., \& Muda, I. (2020). Dampak pandemi Covid-19 terhadap perekonomian Indonesia. Jurnal Benefita, 5(2), 212-224.

Nicola, M., Alsafi, Z., Sohrabi, C., Kerwan, A., Al-Jabir, A., Iosifidis, C., Agha, M., \& Agha, R. (2020). The socio-economic implications of the coronavirus pandemic (COVID-19): A review. International Journal of Surgery (London, England), 78, 185.

Novianti, N., Endri, E., \& Darlius, D. (2018). Kepuasan Pelanggan Memediasi Pengaruh Kualitas Pelayanan dan Promosi terhadap Loyalitas Pelanggan. MIX: Jurnal Ilmiah Manajemen, 8(1), 90-108.

Pakpahan, A. K. (2020). Covid-19 Dan Implikasi Bagi Usaha Mikro, Kecil, Dan Menengah. Jurnal Ilmiah Hubungan Internasional, 59-64.

Pradiani, T. (2017). Pengaruh sistem pemasaran digital marketing terhadap peningkatan volume penjualan hasil industri rumahan. Jurnal Ilmiah Bisnis Dan Ekonomi Asia, 11(2), 46-53.

Pranoto, P., Jasmani, J., \& Marayasa, I. N. (2019). Pelatihan Digital Marketing Untuk Peningkatan Perekonomian Anggota Karang Taruna Al Barkah Di Kampung CicayurTangerang. Jurnal Pengabdian Dharma Laksana, 1(2), 250-258.

Priambada, S. (2015). Manfaat Penggunaan Media Sosial Pada Usaha Kecil Menengah (Ukm). Seminar Nasional Sistem Informasi Indonesia, November, 2-3.

Purwana, D., Rahmi, R., \& Aditya, S. (2017). Pemanfaatan Digital Marketing Bagi Usaha Mikro, Kecil, Dan Menengah (UMKM) Di Kelurahan Malaka Sari, Duren Sawit. Jurnal Pemberdayaan Masyarakat Madani (JPMM), 1(1), 1-17.

Putra, S. H. (2020). Pengembangan UMKM, Pariwisata dan New Normal. Merdeka Kreatif Di Era Pandemi Covid-19: Suatu Pengantar, 1, 43.

Setiawati, I., \& Widyartati, P. (2017). Pengaruh Strategi Pemasaran Online Terhadap Peningkatan Laba UMKM. PROCEEDINGS, $1(1)$.

Silalahi, D. E., \& Ginting, R. R. (2020). Strategi Kebijakan Fiskal Pemerintah Indonesia Untuk Mengatur Penerimaan dan Pengeluaran Negara Dalam Menghadapi Pandemi Covid-19. Jesya (Jurnal Ekonomi \& Ekonomi Syariah), 3(2), 156-167.

Soetjipto, N. (2020). Ketahanan UMKM Jawa Timur Melintasi Pandemi Covid-19. K-Media.

Suharyanto, A. (2016). Surat Kabar Sebagai Salah Satu Media Penyampaian Informasi Politik pada Partisipasi Politik Masyarakat. Jurnal Administrasi Publik (Public Administration Journal), 6(2), 123-136.

Sulistiani, S. (2017). Pengaruh kualitas produk dan promosi terhadap keputusan pembelian yang berdampak pada loyalitas pelanggan pada produk hydro coco Pt kalbe farma. EDUKA: Jurnal Pendidikan, Hukum, Dan Bisnis, 2(1).

Suryani, I. (2014). Pemanfaatan Media Sosial Sebagai Media Pemasaran Produk dan Potensi Indonesia Dalam Upaya Mendukung ASEAN Community 2015.(Studi Social Media Marketing Pada Twitter Kemenparekraf RI dan Facebook Disparbud Provinsi Jawa Barat). Jurnal Komunikasi, 8(2), 123-138.

Thaha, A. F. (2020). Dampak covid-19 terhadap UMKM di Indonesia. BRAND Jurnal Ilmiah Manajemen Pemasaran, 2(1), 147-153. 
134 Pinisi Business Administration Review

Volume 2 Nomor 2, September 2020. Hal 123-134

Tjahjaningsih, E. (2016). Pengaruh Citra dan Promosi Terhadap Kepuasan Pelanggan Serta Dampaknya Terhadap Loyalitas Pelanggan (Studi Pada Pelanggan Supermarket Carrefour di Semarang). Media Ekonomi Dan Manajemen, 28(2).

Tresnawati, Y., \& Prasetyo, K. (2018). Pemetaan konten promosi digital bisnis kuliner kika's catering di media sosial. PRofesi Humas, 3(1), 102-119.

Tutiasri, R. P., Febriyanti, S. N., Huzain, A. F., \& Nugroho, A. S. (2020). Creative Marketing Strategies of Sembung Batik. 423(Imc 2019), 387-396. https://doi.org/10.2991/assehr.k.200325.030

Untari, D., \& Fajariana, D. E. (2018). Strategi Pemasaran Melalui Media Sosial Instagram (Studi Deskriptif Pada Akun@ Subur_Batik). Widya Cipta: Jurnal Sekretari Dan Manajemen, 2(2), 271-278.

Wulandari, D. A., \& Setyawati, A. (2018). Strategi Pemasaran Perusahaan Logistik. Jurnal Manajemen Transportasi \& Logistik, 5(2), 95-104. 